\title{
Objawy ze strony narządu wzroku w guzie móżdżku. Doniesienie wstępne
}

\section{The ophthalmologic signs in cerebellum tumor. Preliminary report}

\author{
Lidia Puchalska-Niedbał', Urszula Kulik¹, Dariusz Jeżewski², Paweł Kawalec², Wojciech Lubiński', \\ Ireneusz Kojder ${ }^{2}$
}

${ }^{1}$ Katedra i Klinika Okulistyki Pomorskiego Uniwersytetu Medycznego w Szczecinie

al. Powstańców Wlkp. 72, 70-111 Szczecin

Kierownik: prof. dr hab. n. med. Wojciech Lubiński

${ }^{2}$ Katedra i Klinika Neurochirurgii Pomorskiego Uniwersytetu Medycznego w Szczecinie

ul. Unii Lubelskiej 1, 71-252 Szczecin

Kierownik: prof. dr hab. n. med. Ireneusz Kojder

\begin{abstract}
SUMMARY
Introduction: The aim of the study was an analysis of ocular symptoms coexisting with the tumour of the cerebellum.

Patients and methods: The study included 14 patients in the age between 21-55 years old with the tumor of cerebellum, who were operated in the Neurosurgery Clinic Pomeranian Medical University in Szczecin. The comprehensive ophthalmic examination were performed before and after 5 days from surgery. The examinations included evaluation of: pupillary reactions, visual acuity, fundus ophthalmoscopy, intraocular pressures, eye motility, visual field, optometrical tests and visual manual localization test. Results: The symptoms found before surgery of cerebellum tumors: diplopia (3 persons), early papilloedema (4 persons), nystagmus ( 2 persons), lack ( 5 persons) and weakened of
\end{abstract}

\section{STRESZCZENIE}

Wstęp: Celem pracy była analiza objawów ze strony narządu wzroku współistniejących z chorobą zasadniczą (guzy móżdżku). Pacjenci i metody: Badaniem objęto 14 chorych w wieku 21-55 lat z guzem móżdżku operowanych w Klinice Neurochirurgii Pomorskiego Uniwersytetu Medycznego w Szczecinie. Pacjentów badano okulistycznie przed zabiegiem i w 5 . dobie po zabiegu. Badania obejmowały ocenę przedniego odcinka i dna oka, akomodacji, widzenia obuocznego testami w wolnej przestrzeni i na synoptoforze oraz badanie wzrokowej przestrzennej lokalizacji ręcznej.

Wyniki: Przed operacją stwierdzono dwojenie (3 osoby), objawy początkowej tarczy zastoinowej (4 osoby), oczopląs (2 osoby), convergence reflex ( 3 persons), latent strabismus ( 5 persons), manifest strabismus ( 3 persons). On the fifth day after the surgery were found: nystagmus ( 1 person), lack ( 5 persons) and weakened of the convergence reflex ( 3 persons). Visual manual localization was disparate depending on location of the tumor in the cerebellum; prevailed crossed and uncrossed localizations. Conclusions: 1 . The natural dynamic of the tumor and surgical damage to the posterior cranial cavity structures can be monitored by assessment of the condition of the organ sight. 2 . It is recommended to make the visual manual localization tests such as exponent disorders of senso-motorical deviations, which may occur in the patients with the cerebellum tumor.

Key words: tumor of cerebellum, diplopia, strabismus, visual manual localization. brak zbieżności (5 osób), słabą zbieżność (3 osoby), zez ukryty (5 osób) oraz zez jawny ( 3 osoby). Po operacji w 5. dobie stwierdzono: oczopląs (1 osoba), brak zbieżności (5 osób) i słabą zbieżność ( 3 osoby). Wzrokowa lokalizacja ręczna była różna w zależności od umiejscowienia guza móżdżku; przeważała lokalizacja skrzyżowana lub nieskrzyżowana.

Wnioski: 1. Dynamika naturalnego i chirurgicznego uszkodzenia struktur tylnej jamy czaszkowej może być monitorowana oceną stanu narządu wzroku. 2. Zaleca się badanie przestrzennej lokalizacji wzrokowej jak wykładnika zaburzeń sensomotorycznych, które mogą występować u chorych z guzami móżdżku.

Słowa kluczowe: guz móżdżku, dwojenie, zez, wzrokowa lokalizacja przestrzenna.

\section{WSTĘP}

Objawy okulistyczne związane z patologią móżdżku i okolic mogą być spowodowane upośledzeniem przepływu krwi w oczodole, szczególnie krwi żylnej, jakie może zaistnieć na skutek wzmożonego ciśnienia w jamie czaszki. Wówczas nieprawidłowe ukrwienie struktur gałki ocznej może dać objawy chwilowego zaniewidzenia, ubytków w polu widzenia czy ślepoty. Zaburzenie krążenia dotyczy całej zawartości oczodołu, również mięśni okoruchowych, zmieniając ich czynność (dwojenie, zez). Z drugiej strony mogą wystąpić objawy dysfunkcji drogi wzrokowej (ślepota, zaniewidzenie), które przypuszczalnie będą generowane przez móżdżek w momencie, gdy zostanie zaburzone powiązanie neurologiczne móżdżku z resztą mózgu.

Biorąc pod uwagę ograniczoną poprzez pojemność czaszki przestrzeń dla rozwoju nowotworu, a i obecność stosunkowo gęsto umiejscowionych w małej przestrzeni ośrodków nerwowych, uzasadnione jest oczekiwać, że kontrolowane parametry czynności układu wzrokowego ulegną zmianie symptomatycznej dla obecności procesu wypierającego móżdżku. 
Celem pracy była wstępna analiza objawów ze strony narządu wzroku występujących u chorych z procesem wypierającym w tylnej jamie czaszkowej. Autorom przyświecała przy tym idea określenia przydatności obserwacji dynamiki nieuraźliwie uzyskanych objawów oftalmologicznych w procesie rozpoznania guza móżdżku i śledzenia ryzyka w przebiegu pooperacyjnym

\section{PACJENCI I METODY}

Badaniem objęto 22 dorosłych pacjentów (wiek 21-55 lat) z guzem móżdżku i okolic, którzy byli operowani w latach 2012-2014 w Klinice Neurochirurgii Pomorskiego Uniwersytetu Medycznego w Szczecinie (PUM). Pacjentów badano okulistycznie przed operacją (22 chorych) oraz w 5. dobie (14 chorych) po operacji guza móżdżku. Z analizy wykluczono 8 pacjentów, u których badania kontrolne ujawniły inne choroby w obrębie ośrodkowego układu nerwowego (OUN).

Przeprowadzone w Klinice i Katedrze Okulistyki PUM badania obejmowały wywiad, pełne badanie okulistyczne: ostrość wzroku do dali (tablice Seleny), wady refrakcji (autorefraktometr), stan przedniego odcinka oka (biomikroskop - lampa szczczelinowa), dno oka (soczewka Volka, oftlamoskop), akomodację (punkt bliży wzrokowej każdego oka, punkt bliży konwergencyjnej), ustawienie oczu (test Hirshberga, cover-test, test pryzmatyczny), ruchomość oczu w 6 podstawowych kierunkach spojrzenia, widzenie obuoczne (test Maddoxa do dali z 5 m, test Maddoxa do bliży z $30 \mathrm{~cm}$, test z kolorowymi filtrami, test Bagoliniego oraz badanie na synoptoforze - jednoczesna percepcja, fuzja oraz jej zakres konwergencyjny i dywergencyjny, a także stereoskopia). Wzrokową lokalizację przestrzenną sprawdzano za pomocą ruchów rąk w kierunku obiektu świetlnego, posługując się lokalizatorem ręcznym. Sprawdzano trafność ruchów rąk w kierunku obserwowanego jednoocznie obiektu świetlnego, bez możliwości kontroli wzrokiem położenia ręki wskazującej. Testy wskazywania obiektu położonego na wprost były wykonywane 10-krotnie dla każdej ręki i dla każdego oka. Badania wykonywano w jednakowych warunkach (w tym samym pomieszczeniu, w ciemni i w ciszy), które eliminowały bodźce mogące mieć wpływ na wyniki lokalizacji. Uczestnictwo w badaniu było dobrowolne, po uzyskaniu pisemnej zgody pacjenta. Zgoda komisji bioetycznej wydana dnia 2 kwietnia 2012 r. nr KB-0012/40/12. Wyniki oceniano zarówno pod względem uzyskania równowagi motorycznej, jak i poprawy sensorycznej.

\section{ANALIZA STATYSTYCZNA}

W celu oszacowania ryzyka występowania patologii w zależności od różnych czynników zastosowano model regresji logistycznej. Wyniki opisano przez podanie względnego ryzyka (OR) wraz z 95\% przedziałem ufności oraz prawdopodobieństwa. Prawdopodobieństwo w modelu tym liczono testem $\chi^{2}$ Pearsona lub dwustronnym dokładnym testem Fishera.
Za różnice istotne statystycznie we wszystkich przeprowadzonych testach uznano te, dla których prawdopodobieństwo $p<0,05$. Poziom istotności $p=0,051-0,099$ oznaczono jako trend na granicy istotności statystycznej.

Analizy statystyczne przeprowadzono przy pomocy programu statystycznego STATA 11.

\section{WYNIKI}

Objawy ze strony narządu wzroku zgłaszane przez pacjentów przed operacją guza to kresowe dwojenie (3 osoby) i obniżona ostrość wzroku u 3 osób w 1 oku (3/50 - 1 osoba; 0,4 - 1 osoba; 0,6 - 1 osoba). Przednie odcinki oczu były prawidłowe u wszystkich badanych. Na dnie oczu obserwowano zatarcie granic od góry i dołu (3 chorych), zatarcie wszystkich granic (1 chory), poszerzenie naczyń żylnych (3 chorych), drobne smugowate wybroczyny tuż przy tarczy od dołu i góry (1 chory). Oczopląsoidalne poziome szarpane drgania oczu przy skrajnym spojrzeniu do boku stwierdzono u 2 osób, zaburzenia zbieżności u 8 osób - brak u 5, słaba u 3 chorych (tab. 1).

Badania optometryczne wykazały egzoforię $\left(3-10^{\circ}\right)$ u 3 osób, esoforię $\left(2-4^{\circ}\right)$ u 3 chorych, zez jawny u 3 osób, brak fuzji konwergencyjnej u 2 osób oraz brak fuzji dywergencyjnej u 5 osób. (tab. 2).

TABELA 1. Zaburzenia ze strony narządu wzroku u pacjentów z guzem móżdżku przed operacją i po

\begin{tabular}{lcc}
\multicolumn{1}{c}{ Objawy } & \multicolumn{2}{c}{ Liczba chorych } \\
\cline { 2 - 3 } & $\begin{array}{c}\text { przed } \\
\text { operacją }\end{array}$ & po operacji \\
\hline Dwojenie & 3 & 0 \\
\hline Słabsze widzenie & 3 & 2 \\
\hline Dno oka: zatarcie granic tarczy nerwu II & 4 & 2 \\
\hline Poszerzenie naczyń żylnych & 2 & 1 \\
\hline Oczopląs & 2 & 1 \\
\hline Brak zbieżności & 5 & 5 \\
\hline Słaba zbieżność & 3 & 3
\end{tabular}

TABELA 2. Badania optometryczne pacjentów z patologią móżdżku przed operacją i po

\begin{tabular}{lcc} 
& \multicolumn{2}{c}{ Liczba chorych } \\
\cline { 2 - 3 } & $\begin{array}{c}\text { przed } \\
\text { operacją }\end{array}$ & po operacji \\
\hline Egzoforia & 3 & 3 \\
\hline Esoforia & 2 & 1 \\
\hline Zez jawny zbieżny & 1 & 1 \\
\hline Zez jawny rozbieżny z komponentem & 2 & 2 \\
pionowym & 11 & 11 \\
\hline Test Filtrowy + & 11 & 11 \\
\hline Bagolini + & 14 & 14 \\
\hline Jednoczesna + percepcja & 12 & 12 \\
\hline Fuzja konwergencyjna & 9 & 9 \\
\hline Fuzja dywergencyjna & & \\
\hline
\end{tabular}




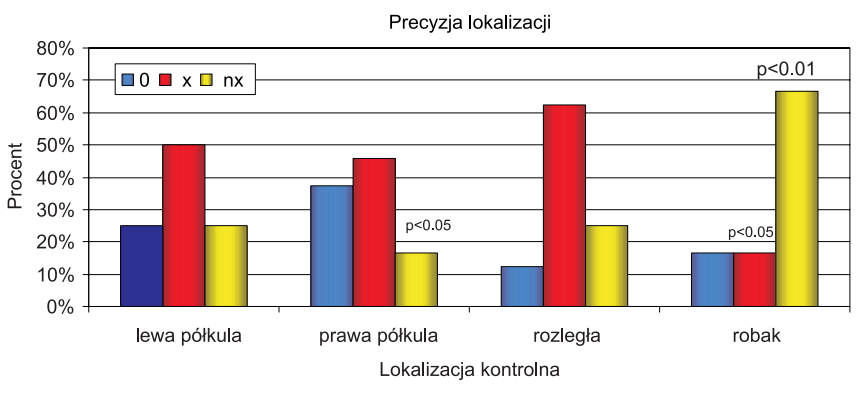

o - lokalizacja precyzyjna, x - lokalizacja skrzyżowana, nx - lokalizacja nieskrzyżowana

RYCINA 1. Wzrokowa lokalizacja przestrzenna ręczna w zależności od lokalizacji patologii w obrębie móżdżku

Wzrokowa lokalizacja przestrzenna ręczna u badanych pacjentów różniła się w zależności od lokalizacji zmiany patologicznej w obrębie móżdżku. Dla umiejscowionej patologii w móżdżku w obrębie robaka precyzyjność lokalizacji istotnie statystycznie różniła się od pozostałych lokalizacji - przeważała lokalizacja nieskrzyżowana $(\mathrm{p}<0,05)$. Dla tej samej lokalizacji statystycznie istotnie najmniej było lokalizacji skrzyżowanej ( $\mathrm{p}<0,05)$. U osób z patologią obejmującą prawą półkulę móżdżku obserwowano najmniejszy procent chorych z lokalizacją nieskrzyżowaną, który różnił się statystycznie istotnie $(\mathrm{p}<0,05)$ w porównaniu do innych lokalizacji guza. Przy patologii całego móżdżku (określono na wykresie - rozległa zmiana) największy odsetek osób miało lokalizację skrzyżowaną - ponad 60\% (ryc. 1).

\section{DYSKUSJA}

Każdorazowy wzrost ciśnienia wewnątrzczaszkowego może przekładać się na utrudnienia odpływu żylnej krwi z oczodołu, dając typowy obraz tego zjawiska - tarczę zastoinową. U 3 pacjentów obserwowano na dnie oczu poszerzenie naczyń żylnych na tarczy nerwu wzrokowego, zatarcie granic tarczy u 2 osób, w tym u 1 osoby niewielkie smugowate wybroczyny tuż przy tarczy od góry skroni i od dołu przed zabiegiem operacyjnym. Objawów tych nie stwierdzano w badaniu kontrolnym w 5. dobie po operacji.

Obniżenie ostrości widzenia od 0,6 do 3/50 stwierdzono u 3 chorych przed operacją guza móżdżku, w tym u 1 chorego było nabyte w okresie dzieciństwa z powodu zeza $(\mathrm{OP}=0,4)$, natomiast u pozostałych 2 chorych spowodowane było skurczem akomodacji (w badaniu refrakcji krótkowzroczność -1,5D; -2,50D), który ustąpił po podaniu mydriatyków (1\% tropicamidum) [1].

Oczopląsoidalne ruchy przy skrajnych spojrzeniach w bok były obecne u 2 chorych przed zabiegiem i utrzymywały się w badaniu w 5 . dobie po operacji. Ten rodzaj oczopląsu często jest opisywany w uszkodzeniach izolowanych móżdżku, w mieszanych uszkodzeniach pnia mózgu i móżdżku [2].

Przy poziomym poruszaniu się oczu biorą udział mięśnie proste przyśrodkowe i boczne, które unerwione są odpowiednio przez nerw okoruchowy (III) i nerw odwodzący (VI). Przy generalizowaniu poziomego ruchu oczu czynności jąder nerwu okoruchowego i nerwu odwodzącego koordynowane są przez pęczek przyśrodkowy podłużny.
Lokalizacja ośrodka regulującego ruchy gałek ocznych prawdopodobnie znajduje się w obrębie móżdżku. Zaburzenia wolnego śledzenia obu oczami oraz problemy związane z utrzymaniem spojrzenia w danym kierunku mogą mieć źródło w uszkodzeniach ośrodków w móżdżku [2].

W momencie kierowania wzroku na bliską lub dalszą odległość procesy zachodzące w obrębie oka (skurcz/rozluźnienie mięśnia rzęskowego, zmiana kształtu soczewki) są kontrolowane na poziomie kory. Modyfikowanie wszystkich reakcji nastawczych oka przypuszczalnie odbywa się w okolicy przedpokrywowej, pokrywie śródmózgowia oraz w obrębie móżdżku.

Widzenie obuoczne przestrzenne jest prawidłowe wówczas, gdy oglądany obraz pada na takie same części siatkówek obu oczu. W warunkach prawidłowych, kiedy oczy ustawione są równolegle, obrazy padające na niekorespondujące części siatkówek powodują dwojenie. Poprzez ruchy nastawcze oczu wergencyjne (zbieżny lub rozbieżny w zależności od odległości oglądanego przedmiotu) zmienia się ustawienie osi widzenia w obu oczach, które pozwala na wyeliminowanie dwojenia. Dzięki takiemu „nastawianiu oczu” możliwe jest utrzymanie fuzji dwóch obrazów widzianych pod nieco innym kątem przez każde oko („zlanie” w pojedynczy, wyraźny obraz).

W sytuacji kiedy okresowo lub stale ustawienie oczu jest nieprawidłowe, pojawia się okresowy zez bądź stały zez jawny. W świeżo nabytych zezach zawsze występuje dwojenie, którego przyczyną może być albo nierównowaga mięśni okoruchowych spowodowana rozregulowaniem ośrodka nadrzędnego, któremu ten proces podlega (być może również znajdującego się w móżdżku), albo osłabienie impulsów biegnących w nerwach (III, IV, VI) spowodowane pośrednim uciskiem przez podwyższone ciśnienie śródczaszkowe bądź bezpośrednim uciskiem guza, który znajduje się na drodze przebiegu tych nerwów. W obserwowanej grupie chorych przejściowe dwojenie występowało u 3 chorych przed zabiegiem, natomiast nie obserwowano dwojenia u pacjentów w badaniu kontrolnym w 5. dobie.

Odruch zbieżnego ustawiania oczu jest bardzo ważnym procesem w chwili kierowania wzroku na przedmioty w bliskiej odległości (komputer, smartfon, czytanie książek), pozwala na jednoczesną pracę obu oczu. Niedomoga lub brak zbieżności objawiają się zamazanym lub okresowo podwójnym widzeniem przy patrzeniu z bliska, bólami głowy i oczu lub nawet zaburzeniami równowagi. Osoby z takimi dolegliwościami poddawane są szerokiej diagnostyce, łącznie z obrazową, które to badania zwykle wypadają negatywnie. Obecnie trudno jest wytłumaczyć brak (u 5 chorych) i niedomogę (u 3 chorych) odruchu zbieżnego stwierdzonego u chorych przed operacją guza móżdżku oraz utrzymywanie się tego stanu w badaniu kontrolnym po operacji. Objaw niedomogi lub całkowity brak zbieżności niekoniecznie muszą być związane z porażeniem obwodowym nerwu III. Podłoże występowania tego rodzaju anomalii jest nadal dyskutowane.

Istotną rolę móżdżku w procesie wolnych ruchów zbieżnych oczu starali się udowodnić autorzy w wielu badaniach naukowych najpierw na zwierzętach, a później opierając się na obserwacjach pacjentów po udarach móżdżku [3]. 
Patologiczny skurcz akomodacji spowodowany jest nadmiernym skurczem mięśnia rzęskowego, będącym najczęściej następstwem przedłużającej się pracy z bliska bez zachowania odpowiedniej higieny [1]. Główne skargi zgłaszane przez osoby ze skurczem akomodacji to niewyraźne widzenie z daleka (z początku w momencie przestawiania widzenia z bliska bezpośrednio na widzenie na dalszą odległość), bóle głowy o niewyjaśnionej przyczynie, a w końcu pojawienie się krótkowzroczności.

U jednego chorego stwierdzono skurcz akomodacji przebiegający z niepokojącymi subiektywnymi objawami opisywanymi jako nagłe zaniewidzenie po jednej stronie, powtarzające się kilka razy w ciągu dnia, z towarzyszącym bólem głowy. W badaniu okulistycznym chorego stwierdzono niską ostrość wzroku w lewym oku (3/50), autorefraktometr wykazał krótkowzroczność $-2,5$ D. Po podaniu 1\% tropikamidum (3×) ostrość wzroku powróciła do 1,0, a w refraktometrze stwierdzono nadwzroczność $(+1,5 \mathrm{D})$. Skurcz akomodacji dający nagłe niepokojące pacjenta objawy przyczynił się do pogłębionej diagnostyki, w tym obrazowej, i rozpoznania zmiany w tylnym dole czaszki. Trudno wiązać to zjawisko z podstawową chorobą, ponieważ skurcz akomodacji coraz częściej jest spotykany u młodzieży uczącej się i pracującej na komputerach, laptopach i smartfonach.

Obrazem lokalizacji przestrzennej jest precyzyjny odruch optomotoryczny wyrażony w sprawnym ruchu kończyn lub zwrocie ciała w kierunku bodźca. Wzrokowa lokalizacja przestrzenna w życiu praktycznym przejawia się zdolnością szybkiej dokładnej oceny wzrokowej otaczających zjawisk lub precyzją zamierzonego ruchu w kierunku działającego bodźca. Warunkiem prawidłowej koordynacji wzrokowo-ruchowej jest pełnosprawny ośrodkowy układ nerwowy [4]. Wzrokowa lokalizacja ręczna jest funkcją kojarzeniową OUN niezależną od dominacji półkul mózgowych [5]. Lokalizacja wzrokowa ręczna jest prawidłowa, jeżeli ruchy ręki w kierunku wskazywanego obiektu odpowiadają rzeczywistości, tzn. kierunkowi rzeczywistego przedmiotu (adekwatna reakcja organizmu). Kiedy ruch ręki odbywa się w innym kierunku, lokalizacja jest fałszywa, niezgodna z rzeczywistością (nieadekwatna reakcja organizmu). Taką lokalizację obserwowano u osób z uszkodzeniami w obrębie móżdżku i tylnej jamy czaszki. Baranowska-George i wsp. [5] w swoich badaniach stwierdzili, że lokalizacja tego samego oka i tej samej ręki czasem wykazywała większe wychylenia niż w oku drugim, ponadto potwierdzili częstsze występowanie lokalizacji skrzyżowanej. Przy samoistnym krwiaku śródmózgowia w prawym płacie skroniowym wstępna lokalizacja miała tendencję do przesunięcia w prawą stronę przy badaniu lewą ręką. Autorzy również stwierdzili dość duży rozrzut lokalizacji wstępnej z tendencją przesunięcia w stronę prawą [6].

Technika badania wzrokowej lokalizacji ręcznej dla każdego oka i ręki oraz stosowanie po 10 powtórzeń pozwala na skorygowanie ruchu ręki przy pierwszych nietrafnych wskazywaniach u osób zdrowych. Również tę samą technikę badania stosuje się z pryzmatem 30DP, jak i po pryzmacie z drugiego oka. W pracy zostały przedstawione wyniki lokalizacji wstępnej przed próbą prowokacyjną z pryzmatem 30DP, które to wyniki zostaną przedstawione w kolejnych doniesieniach. Badanie wzrokowej lokalizacji przestrzennej ręcznej u chorych z guzami móżdżku w dużym odsetku wykazało brak precyzji lokalizowania zarówno lewą, jak i prawą ręką, ponadto ruchy ręki nie były płynne w danym kierunku, lecz odbywały się skokowo, niepewnie, czasami zbyt energicznie. Odchylenia ręki od lokalizowanego obiektu wynosiły $2-8^{\circ}$.

Uzyskane wyniki badań wykazały brak koordynacji wzrokowo ręcznej oraz brak precyzji ruchu rąk w kierunku obserwowanego bodźca u chorych z guzami móżdżku. Pomimo 10 prób lokalizowania danego obiektu każdym okiem i każdą ręką, pacjenci nie wykazywali poprawy precyzji wskazywania obserwowanego obiektu. U zdrowych osób wzrokowa lokalizacja przestrzenna ręczna przebiega inaczej, mianowicie w krótkim czasie (po 1-2 ruchach ręki) jest precyzyjna, utrzymuje się przez resztę badania. Kora mózgowa osób zdrowych szybko uczy się, zjawiska tego nie obserwowano u osób z guzami móżdżku. Czyżby występował braku kooperacji pracy móżdżku i całej kory mózgowej?

Wzrokowa lokalizacja przestrzenna wymaga funkcji móżdżku cechującej się sprawną sekwencją aktywności zbalansowanych naprzemiennych kierunków: „do i od”. Zwykle jest to obserwowane w diadochokinezie, która jest efektem płynnej zmiany napięcia mięśni antagonistycznych przy zachowanej pamięci proceduralnej. Od niedawna znane są dowody na udział móżdżku w podobnie zbalansowanym procesie kognitywnym umysłu jak diadochoingenia i uczuciowym jak diadochotymia, co określane jest jako balance of thoughts [7]. Obserwacje te czynią kuszącym poszukiwanie symptomatyki w odnośnym zakresie neurooftalmologicznym.

Na podstawie badań własnych i doniesień z literatury można uznać, że celowym wydaje się wykorzystanie testu dynamiki wzrokowej lokalizacji przestrzennej do badań osób z zaburzeniami w obrębie móżdżku.

\section{WNIOSKI}

1. Dynamika naturalnego i chirurgicznego uszkodzenia struktur tylnej jamy czaszkowej może być monitorowana oceną stanu narządu wzroku.

2. Zalecane jest badanie przestrzennej lokalizacji wzrokowej jako wykładnika zaburzeń sensoryczno-motorycznych, które mogą występować u chorych z guzami móżdżku.

\section{PIŚMIENNICTWO}

1. Puchalska-Niedbat L.: Akomodacja - obecny stan wiedzy. Okulistyka. 2013, 16 (1), 25-27.

2. Jadanowski K., Budrewicz S., Koziorowska-Gawron E.: Zaburzenia gałkoruchowe w chorobach ośrodkowego układu nerwowego. Pol Przegl Neurol. 2010, 6 (4), 202-211.

3. Sander T., Sprenger A., Neumann G., Machner B., Gottschalk S., Rambold H. et al: Vergence deficits in patients with cerebellar Lesions. Brain. 2009, $132,103-115$. 
4. Baranowska-George T.: Lokalizacja wzrokowa jako wyraz funkcji układu nerwowego wzrokowego ośrodka. Klin Oczna. 1980, 82, 265-268.

5. Baranowska-George T., Kojder I., Kowerska D., Kopacka W.: Dominacja półkuli mózgu a wzrokowa lokalizacja przestrzenna ręczna. Klin Oczna. $1990,92,134-136$
6. Baranowska-George T., Kojder I.: Wzrokowa lokalizacja przestrzenna po przebytych samoistnych krwiakach śródmózgowia. Klin Oczna. 1987, $89,46-49$.

7. Schmahmann J.D., Weilburg J.B., Sherman J.C.: The neuropsychiatry of the cerebellum - insights from the clinic. Cerebellum. 2007, 6 (3), 254-267. 